\title{
Sprzeczności i antynomie jako przypadłość demokracji
}

\author{
Contradictions and Antinomies \\ as Afflictions of Democracy
}

\author{
Edward Karolczuk*
}

\begin{abstract}
Abstrakt
Cechą każdego ustroju demokratycznego - w tym także neoliberalnego - ze względu na jego genezę i pełnione funkcje, są pewne antynomie. Celem wyznaczonym w opracowaniu jest próba odpowiedzi na pytanie o to, czy zasadne jest stosowanie kategorii sprzeczności logicznej i sprzeczności dialektycznej w badaniu zagadnienia demokracji. Aby odpowiednio zrozumieć wewnętrzne sprzeczności demokracji neoliberalnej konieczne jest, zdaniem autora, posługiwanie się dialektyką - tak, jak ją rozumieli G.W.F. Hegel i K.Marks.

Punktem wyjścia w rozważaniach autora jest przywołanie pojęcia dialektyki w kontekście analizy demokracji liberalnej. Kolejnymi syntetycznie omówionymi pojęciami w części wstępnej artykułu są pojęcia sprzeczności i antynomii oraz ich rodzaje, istotne $\mathrm{z}$ punktu widzenia tematu i celu opracowania. Pozwalają ona na wska-
\end{abstract}

\begin{abstract}
Antinomies are a feature of any democratic system - including neoliberal ones - due to its genesis and functions. Edward Karolczuk's aim in this article is to examine whether it is justifiable to use the categories of logical and dialectical contradiction in the study of democracy. In order properly to understand the internal contradictions of neoliberal democracy, it is necessary, in Karolczuk's opinion, to use dialectics in the sense in which it was understood by G.W.F. Hegel and K. Marx.

At the starting point of his reflections, Karolczuk summons the concept of dialectics in the context of the analysis of liberal democracy. Other concepts synthetically discussed in the introductory part of the article, are those of contradiction and antinomies and their types, relevant from the point of view of the topic and purpose of this discussion. They allow him to identify, in the final
\end{abstract}

* Nauczyciel emeryt; (edward.karolczuk@gmail.com); iD https://orcid.org/0000-0002$1423-3871$ 
zanie w ostatniej części typowych antynomii demokracji (m.in. ,władzy ludu”, równości, wolności, większości i mniejszości).

Słowa kluczowe: demokracja, antynomie, sprzeczności, dialektyka, „władza ludu”, równość, wolność, większość, mniejszość part of the article, antinomies typical of democracy (e.g., "the power of the people", equality, freedom, majority, and minority).

Keywords: democracy, antinomies, contradictions, dialectics, "power of the people", equality, freedom, majority, minority

Wszelka demokracja, w tym neoliberalna, ze względu na swoją genezę i funkcje skazana jest na antynomie. „Władza ludu”, nawet jeśli w szczególnych momentach historii ma miejsce, to z czasem nieuchronnie okazuje się antynomią, gdyż „władza nad ludem” okazuje się dominującą nad „władzą ludu nad władzą”. Cel niniejszej publikacji stanowi danie odpowiedzi na pytanie o to, czy zasadne jest stosowanie kategorii sprzeczności logicznej i sprzeczności dialektycznej w badaniu zagadnienia demokracji? Aby zrozumieć wewnętrzne sprzeczności i mechanizmy samozaprzeczenia w demokracji neoliberalnej, konieczne staje się posługiwanie się dialektyką - w rozumieniu Heglowsko-Marksowskim. Stosowanie Heglowsko-Marksowskiej dialektyki pozwala na przełamanie wielu dogmatów występujących w literaturze przedmiotu i w publicystyce.

\section{Dialektyczne podejście do analizy demokracji liberalnej}

Dialektyka (z greckiego dialektiké) w filozofii stanowi metodę rozumowania albo teorię ontologiczną, w myśl której rzeczywistość jest ujmowana w dynamicznym rozwoju ${ }^{1}$. Za naczelne prawo logiki Georg Wilhelm Friedrich Hegel uznał prawo dialektyczne, zgodnie z którym każdemu prawdziwemu twierdzeniu odpowiada prawdziwe przeczenie, każdej tezie - antyteza, z których później wyłania się synteza. Nie ma sztywnego podziału między podmiotem i przedmiotem, lecz istnieje całe bogactwo związków i zależności między nimi. Dialektykę heglowską przejął Karol Marks, tworząc z niej teorię rozwoju rzeczywistości materialnej i społecznej oraz podstawę wszelkich projektów ich przekształcania.

Oprócz ogólnych, istnieją także specyficzne przeciwieństwa i sprzeczności, które występują i ścierają się z sobą we wszystkich zjawiskach, instytucjach i procesach społecznych, dopóki one istnieje. Swoiste zespolenie, połączenie czy ostrość sprzeczności i przeciwieństw decydują o specyfice danego zjawiska, in-

${ }^{1}$ W starożytności i średniowieczu mianem dialektyki określano głównie sztukę prowadzenia dyskusji i dochodzenia do prawdy przez ukazywanie sprzeczności w sposobie myślenia rozmówcy lub przez obalanie zaprzeczeń dowodzonych tez. W czasach nowożytnych przeważa jednak pojmowanie dialektyki jako teorii bytu, ukazującej rozwój rzeczywistości w postaci procesu, którego istotę stanowi ścieranie się i jednoczenie przeciwieństw. 
stytucji czy procesu. Sprzeczności nie są tożsame z konfliktem - mogą długo współegzystować $\mathrm{z}$ sobą, ale dopiero w określonych warunkach mogą przerosnąć w sprzeczności antagonistyczne, a te - w konflikty społeczne.

Przejawem niedialektycznego podejścia do problemów liberalnej demokracji jest traktowanie społeczeństwa obywatelskiego jako trwałej jedności i jego tożsamości z państwem, jak również absolutne, niezależne od warunków i okoliczności, ich sobie przeciwstawianie. Tymczasem rozwój liberalnej demokracji nie jest wyjątkiem, dokonuje się również przez powstawanie i rozwiązywanie sprzeczności społecznych i sprzeczności właściwych demokracji. Jednak każde rozwiązanie określonej sprzeczności prowadzi nie do powstania jakiejś idealnej „harmonii”, lecz do wyłonienia się kolejnej sprzeczności. Kwestionowanie tej dialektyki, przedstawianie rozwoju bez sprzeczności, chociaż okresowe kryzysy ekonomiczne i polityczne zadają temu kłam, ma swoje poznawcze i społeczne przyczyny. Dlatego sprzeczności liberalnej demokracji nie można sprowadzać do czyjejś złej woli, subiektywnych błędów poszczególnych polityków, łamania prawa naruszenia zasad etycznych czy ogólnego upadku moralności.

W odniesieniu do problemu demokracji mają również zastosowanie wszystkie trzy prawa dialektyki, tj. prawo jedności walki przeciwieństw, prawo przechodzenia zmian ilościowych $\mathrm{w}$ jakościowe i prawo negacji negacji. $\mathrm{W}$ tych prawach i poprzez te prawa dialektyki realizują się oczywiście interesy bieżące i perspektywiczne określonych klas i warstw społecznych. „Demokracja dialektyczna to taka, która rozwija instrumenty i mechanizmy rządzenia zgodnie z syntezą, która jest wynikiem ruchu tezy i antytezy. To jest postęp w historii. Jej warunkiem wstępnym jest odpowiednia przestrzeń dla różnych światopoglądów i praktyk, które mogą, ale nie muszą, znaleźć miejsce w argumentacji i deliberacji. Podczas gdy demokracja deliberacyjna warunkuje się istnieniem wiedzy poznawczej, demokracja dialektyczna będzie skuteczna nawet $\mathrm{z}$ wiedzą empiryczną, niekoniecznie wykluczając poznanie. O ile demokracja deliberacyjna wymaga wyrafinowania w zakresie wiedzy i języka komunikacyjnego, o tyle demokracja dialektyczna zadowala się organiczną ewolucją instrumentów i mechanizmów rządzenia w oparciu o ich kompetencje komunikacyjne. [...] Na całym świecie rządzące oligarchie mają ograniczony poziom tolerancji wobec ruchu dialektycznego i jego konsekwentnej syntezy w społeczeństwie. Dzieje się tak dlatego, że ich program postępu jest ustalony jako dominujący, a dialektykę postrzegają one nie jako postęp, ale jako blokadę dla swoich projektów postępu. Blokada dla ruchu dialektycznego przez oligarchie realizowana jest generalnie na dwa sposoby. Pierwszym sposobem, do którego uciekają się dominujące oligarchie, w tym dyskursywne elity, jest ignorowanie tezy lub tezy pierwotnej, która istniała na długo przed oddaniem władzy w jej ręce. Zarówno inteligencja, jak i siły rządzące udają wykalkulowaną ignorancję w sprawie istnienia lub pojawienia się antytezy w wyniku praktyki lub dyskursu. Jeśli to nie zadziała, rządząca elita ucieka się do brutalnej siły, często ślepo opresyjnych 
sił zbrojnych, by zniszczyć wszelkie możliwe antytezy. W takich przypadkach elity intelektualne uciekają się do praktyk opisowych, aby unieważnić słuszność antytezy. Elita rządząca znajduje poparcie w takich zapisach i wykorzystuje je jako legitymizację ślepego użycia siły" (Raj, 2012).

W badaniu procesów społeczno-politycznych bardzo istotny jest podział na podmiot i przedmiot. Dialektyka przełamuje typowy dla mechanistycznego materializmu sztywny i dogmatyczny podział między podmiotem i przedmiotem. Przedmiot oddziałuje na podmiot, ale również podmiot oddziałuje na przedmiot i kształtuje go. Każdy określony byt uzyskuje swoją tożsamość w stosunku do innych przedmiotów i podmiotów. Pomiędzy przedmiotem i podmiotem istnieje względna autonomia. Aktywny podmiot nie jest w stanie zapanować nad własnymi wytworami. Jak te związki i zależności są bogate, można ukazać na przykładzie sprzeczności między politykiem a jego wyborcą. Krzysztof Kościuszko napisał m.in.: „Taki demokratyczny polityk nie powinien np. ulegać pokusie korupcji i przekupstwa. W ogóle nie powinien dążyć do wzmocnienia dyktatury nowoczesnych neoliberalnych kapitalistów. Nad czym głowią się liberalni i neoliberalni politycy (mniej lub bardziej akceptujący zasady interwencjonizmu)? Czyż nie nad zniewoleniem tzw. obywateli? Obywatelom przyznaje się wolność podejmowania decyzji, ale w praktyce te decyzje są sterowane; pragnienia obywateli są narzucane, a ich tożsamość kształtowana (chodzi o wytworzenie osobowości rynkowej). Zamiast kontrolować poczynania elit rządzących, masy są przez te elity kontrolowane. [...] Wprost przeciwnie: wielkie korporacje przemysłowo-finansowe o zasięgu międzynarodowym sterują nie tylko wytwarzaniem konsumenckich potrzeb jak największej liczby obywateli, ale także kształtowaniem korzystnych dla siebie stosunków polityczno-społecznych na całym globie ziemskim. Mówi się o budowaniu wolnościowego etosu obywateli, ale w praktyce ten etos rozwija się w ramach i pod kontrolą globalnego (holistycznego) planowania" (Kościuszko, 2015, s. 16-17).

Przeciwko stosowaniu dialektyki jako metody naukowej występuje wielu współczesnych socjologów i politologów, którzy często za podstawę przyjmują poglądy Karla Poppera. Popper, chociaż w młodości należał do kółka socjalistów i brał udział w wykładach z marksizmu na Uniwersytecie Wiedeńskim, w późniejszym okresie zerwał z marksizmem. W słynnym referacie wygłoszonym na seminarium w Canterbury University College Christchurch w Nowej Zelandii w 1937 roku Popper wskazywał, że chociaż interpretacja historii myśli bywa czasami całkiem zadowalająca, to jednak ,interpretacja w terminach metody prób i błędów jest nieco szersza niż w kategoriach dialektyki” (Popper, 1999, s. 526). Uważał, że autorzy postulujący wyodrębnienie logiki dialektycznej „Opierają się wyłącznie na luźnym, mętnym sposobie mówienia. [...] Wszystko to znaczy, że jeśli mielibyśmy godzić się na sprzeczności, byłby to koniec jakiegokolwiek postępu intelektualnego" (Popper, 1999, s. 530). Uznawał, że trzeba zrezygnować ze zręcznych kalamburów i dwuznaczności, jakimi skutkuje odwoływanie się 
do Heglowskiej triady: teza - antyteza - synteza. „Drugim niebezpieczeństwem dialektyki jest jej mglistość. Pozwala ona bez wysiłku narzucać interpretację dialektyczną wszelkiego rodzaju procesom, a nawet przedmiotom" (Popper, 1999, s. 539). Filozof proponował rezygnację z używania niewiarygodnych i niezrozumiałych pojęć dialektyki na rzecz jaśniejszej metody prób i błędów. Odrzucał dialektykę heglowską i marksowską. Był zdania, że „materializm dialektyczny jest czymś jeszcze gorszym od dialektycznego idealizmu. [...] Materialistyczny pierwiastek tej teorii dałby się stosunkowo łatwo przeformułować w taki sposób, że trudno by mu było cokolwiek zarzucić" (Popper, 1999, s. 553). Popper szczególnie mocno zaatakował stosowane przez Karola Marksa prawo negacji negacji, zwłaszcza w odniesieniu do własności prywatnej. Pod koniec swego wykładu Popper musiał przyznać, że „Dialektyka jest jednak metodą na tyle elastyczną, że pozwala wyjaśnić sytuacje nieprzewidziane z równym powodzeniem co przewidziane trafnie. Cokolwiek się zdarzy, okaże się zgodnie z dialektycznym schematem: dialektycy nie mają powodu się obawiać, że przyszły rozwój wydarzeń obali ich prognozy" (Popper, 1999, s. 557). Marksizm jego zdaniem przeistoczył się w spotęgowany i elastyczny dogmatyzm pozwalający unikać wszelkiej krytyki.

Wiele tych sprzecznych i niekonsekwentnych wypowiedzi pokazuje, że stosowanie dialektyki jest obiektywnym wymogiem współczesnej politologii. Cytowany tu już Kościuszko zauważył, że „Popper, krytykując dialektykę Hegla, sam ją w pewnym sensie uprawiał. [...] Dialektyczność Poppera przejawia się w tym, że rozpatrywał on pojęcia i zjawiska w ich oddziaływaniu wzajemnym; np. w tym, że próbował stworzyć syntezę psychologizmu (krytykowanego przez Husserla) z logicyzmem Husserla, syntezę psychologizmu (w intuicjonistycznym wydaniu) z Hilbertowskim formalizmem i z Platońskim esencjalizmem, syntezę konstruktywizmu ze swoiście rozumianym platonizmem" (Kościuszko, 2015, s. 17).

Do wyeliminowania sprzeczności liberalnej demokracji nie doprowadzi ani eliminowanie sprzeczności systemu prawnego, ani osiąganie na poszczególnych etapach moralno-politycznej jedności społeczeństw. Spójność systemu prawnego i jedność moralno-polityczna społeczeństw realizuje się bowiem poprzez rozwiązywanie sprzeczności w ich łonie, a nie ponad społeczeństwami - sprzeczności są zawsze wyrazem określonego poziomu jedności i walki przeciwieństw.

Sprzeczność w rozwoju demokracji to taki proces, którego przebieg jest niezbędną przesłanką jej funkcjonowania i którego realizacja stanowi jednocześnie warunek jej zmian i obumierania jako podstawy dalszego rozwoju. Dlatego liberalna demokracja jest $\mathrm{z}$ jednej strony warunkiem niezbędnym do pokonania systemu feudalnego i rozwoju kapitalistycznej gospodarki rynkowej, a z drugiej strony jej dalszy konsekwentny rozwój zaczyna zagrażać systemowi kapitalistycznemu, dlatego musi być ona w taki czy inny sposób ograniczana. Liberalna demokracja włącza milionowe masy do polityki, czyni je podmiotem historii, 
a jednocześnie stwarza im różnego rodzaju ograniczenia i wykluczenia, głównie poprzez to, że niektórych problemów nigdy nie poddaje pod głosowanie obywateli i w procesie medializacji wywiera ogromny nacisk psychologiczny, aby narzucić im określone poglądy i wartości oraz pożądane zachowania obywatelskie.

Jednym z paradoksów liberalnej demokracji jest to, że władza sprawowana ze społecznego nadania obraca się przeciwko społeczeństwu (Kostecki, 2007, s. 59). Rządzeni udzielają przyzwolenia na działania racjonalne, ale władza opiera się na podporządkowaniu i przymusie. Ciągła konfrontacja pomiędzy dominacją i samorządnością, prawem i przemocą sprawia, że nie można wyeliminować paradoksu polityki. Państwo ma monopol na stosowanie przemocy, ale monopol ten oparty jest na praktycznym przyzwoleniu obywateli.

Daniel Bensaïd pisał, że „rzeczywiste wewnętrzne sprzeczności demokracji [...] wywodzą się już z aporii umowy społecznej. Od czasu, gdy Rousseau ustalił, że »siła nie stanowi prawa«, oraz że »należy być posłusznym jedynie prawowitej władzy«, pojawić się musiało pytanie o podstawy prawowitości oraz o napięcia powstające między tym, co jest zgodne z prawem, a tym co jest prawowite. Zawsze bowiem istnieje możliwość odwoływania się między jednym a drugim. Wpisanie prawa do insurekcji w konstytucję roku II było próbą przełożenia tej sprzeczności na prawo" (Bensaïd , 2012, s. 42).

Umowa społeczna oznacza powstanie zrzeszenia, w którym są dwustronne zobowiązania „między tym, co publiczne, a tym, co prywatne. Zakłada, że każdy kontrahent układa się sam ze sobą - jako członek państwa oraz jako zwierzchnik - a tym samym przyjmuje zobowiązanie wobec całości, której część stanowi. Ale z natury »ciała politycznego« wynika, że zwierzchnik nie może narzucić sobie prawa, któremu miałby być posłuszny. [...] Wynika z tego niemożliwość przedstawicielstwa [...]. To właśnie fundament »demokracji bezpośredniej《" (Bensaïd , 2012, s. 43-44).

\section{Pojęcie sprzeczności i antynomii logicznej}

W logice formalnej za sprzeczność (łac. contradictio) uważa się stosunek między dwoma zdaniami, z których jedno stanowi negację drugiego. Negację zdania przeprowadza się przez dodanie do zdania prawdziwego „nie” lub „,nieprawda, że". Zdaniem zaś wewnętrznie sprzecznym nazywa się zdanie będące koniunkcją dwóch zdań sprzecznych lub dających się przekształcić w tego rodzaju koniunkcję.

W logice formalnej zaleca się postępowanie zgodne z prawem sprzeczności zwanym też zasadą niesprzeczności. W myśli Arystotelesa można wyodrębnić trzy interpretacje tego prawa: interpretację logiczną, mówiącą o tym, że z dwu 
zdań wzajem sprzecznych tylko jedno może być prawdziwe; ontologiczną, mówiącą o tym, że nie może być tak, że coś zarazem jest i nie jest; psychologiczną, mówiącą o tym, że nie da się pomyśleć o żadnej rzeczy, że jest taka i zarazem taka nie jest. Niedopuszczalne jest głoszenie w jednym i tym samym czasie przeciwstawnych twierdzeń o jednym i tym samym, pod jednym i tym samym względem. Każda rzecz może przekształcić się w jeden z dwóch przeciwstawnych stanów, ale nie może przebywać w nich jednocześnie. Według logiki formalnej wszelkie sprzeczności w rozumowaniu są przypadkowe i stanowią wynik „,niesystematyczności”, „niepoprawności” czy „niekonsekwencji” myślenia. W logice formalnej nie uznaje się żadnych sprzeczności dialektycznych tkwiących w przedmiocie czy zjawisku. W logice formalnej wskazuje się, że istnieje contradictio in adiecto (sprzeczność w przydawce), czyli stosunek między dwoma wyrażeniami stanowiącymi składniki wyrażenia złożonego, polegający na tym, że każdy z tych składników jest negacją drugiego lub że pociąga za sobą w pewien sposób negację drugiego.

Sprzeczność ta występuje w oksymoronie (gr. oksýmoron od oksýs „ostry” + morós „tępy, głupi”), który jest sprzecznością i pewną figurą stylistyczną polegającą na metaforycznym zestawieniu z sobą wyrazów o przeciwstawnym i wzajemnie wykluczającym się znaczeniu; antylogią. Oksymoron jest wyrażeniem złożonym z dwóch przeciwstawnych znaczeniowo składników, zwykle z rzeczownika i określającego go epitetu, a także rzeczownika lub czasownika, czasownika i przysłówka - ukazujących właściwości, stany, działania itp. o charakterze paradoksalnym, łączącym $\mathrm{w}$ jedną całość sprzeczne wyrażenia, z zastosowaniem pozornej nielogiczności w celu podkreślenia złożoności obrazu lub pojęcia - przykładowo, totalitarna demokracja, tyrania większości, demokratyczna dyktatura, demokracja ajatollahów, prawdomówny polityk, tolerancyjny dyktator, obowiązkowe wybory. Z kolei pleonazm oznacza taką wypowiedź, w której jedna część wyrażenia powtarza to, co zawiera druga część, np. demokracja ludowa, demokracja większości, demokracja deliberacyjna.

\section{Antynomie}

Antynomia (grec. anti - „przeciw”, nomos - „prawo”) - w rozumieniu logicznym - jest szczególnym rodzajem sprzeczności. Jest to para zdań, z których każde w równym stopniu zasługuje na przyjęcie, lecz jednocześnie są one sprzeczne między sobą i dlatego nie można przyjąć obu. Teza i antyteza w swej wzajemnej negacji są w równym stopniu prawidłowe i konieczne. Klasycznym przykładem antynomii jest tzw. antynomia kłamcy, przypisywana Eubulidesowi z Miletu: „[...] jeśli kłamca mówi, że kłamie, wynika z tego, że kłamie i nie 
kłamie zarazem". Antynomia dosłownie oznacza sprzeczność w prawie, konflikt prawa z samym sobą, teza i antyteza mają tę samą wartość logiczną i w jednakowym stopniu są obiektywnie prawdziwe. Nazwę antynomia odnosi się też często do przypadków, w których rozstrzygnięcie między sprzecznymi stanowiskami nie jest możliwe - wówczas należy jednak mówić o jej nierozstrzygalności. Taka trudność niedająca się przezwyciężyć dlatego, że argumenty za daną tezą równoważą się z argumentami za tezą przeciwną, określana jest jako aporia (z greckiego aporema - „wątpliwość”).

Przykładem antynomii może być teza, że aktywność obywateli jest warunkiem i postawą demokracji, oraz teza przeciwna, że aktywność obywateli nie jest warunkiem i podstawą demokracji. Aby rozstrzygnąć tę antynomię, należy zdawać sobie sprawę z tego, że wszystko zależy od oceny merytorycznego przygotowania aktywnych obywateli do podejmowania decyzji. Innym przykładem antynomii jest stwierdzenie, że pluralizm ideologiczny i polityczny stanowi warunek i podstawę demokracji. W tym wypadku rozstrzygnięcie antynomii zależy od celów programowych i charakteru działających partii politycznych. Czy racjonalny system demokratyczny do utrzymania swej spójności wymaga irracjonalnych poglądów i instytucji? Obywatele, jako podmioty demokracji, w podejmowaniu swoich decyzji są zależni i niezależni; kierują się dążeniem do poznania prawdy i relatywizują prawdę zależnie od swoich interesów. Antynomią jest też stwierdzenie, że najwyższym urzędnikiem może zostać każdy obywatel, i że urząd ten sprawować może jedynie ten, kto zdobędzie większość głosów w wyborach. $Z$ jednej strony władza jest samodzielnym podmiotem politycznym, a z drugiej (z uwagi na oparcie jej na bezwzględnej większości) czyni się z niej marionetkę pozbawioną wolności i autonomii. Kolejna antynomia polega na tym, że władza organizuje na różne sposoby badania statystyczne oczekiwań i nawyków mas, którym zawdzięcza swą władzę, a jednocześnie aktywnie oddziałuje na nie, aż do granic „wytrzymałości”. Antynomia „kłamcy” ma również swoje odzwierciedlenie w demokracji: Jeśli władza mówi, że mówi prawdę, to w ocenie kogoś, kto jej programowo nie ufa, może ona mówić prawdę lub kłamać; Czy władza może sama o sobie orzekać, że mówi prawdę?; Jeśli obywatel mówi prawdę, to jego przeciwnik polityczny musi być kłamcą; Ilekroć przeciwnik polityczny powie cokolwiek, tylekroć musi towarzyszyć mu kłamstwo; Wróg mojego wroga musi być moim przyjacielem. $\mathrm{Z}$ założeń demokracji wynika, że w demokracji parlamentarnej wybierani są mądrzejsi, ale niestety okazuje się niejednokrotnie, że są to przestępcy, chcący wykorzystać immunitet parlamentarny do uniknięcia odpowiedzialności lub skorzystać z niego w celu popełnienia kolejnych przestępstw. A procedury demokratyczne można zastosować do ograniczenia swobód demokratycznych.

Antynomie w logice, traktowane jako pewien proces, stanowią symptom dialektycznej sprzeczności procesu poznania, „moment rozwijającego się pojęcia, moment prawdy-procesu" (Głagolewa, 1981, s. 222). Z kolei G. Batiszczew 
mówił, że: „Proste i bezpośrednie, najostrzejsze starcie tezy i antytezy nazywane antynomia, jest tylko pierwszym aktem tego wieloaktowego dramatu, któremu na imię - sprzeczność dialektyczna” (Batiszczew, 1981, s. 263). „Marks odkrywa sprzeczności systemu kapitalistycznego przede wszystkim jako antynomie tkwiące $\mathrm{w}$ samej istocie rzeczy i odpowiednio $\mathrm{w}$ prawdziwym pojęciu każdego z rzeczywiście zachodzących w niej procesów odkrywa on obiektywnie ukształtowane autonomie. [...] Każda obiektywna posiadająca treść przedmiotową sprzeczność jest początkowo ujmowana teoretycznie jako antynomia" (Rozental, 1977, s. 222-223). Antynomie stanowią subiektywny obraz obiektywnego świata. Analiza historycznego rozwoju pojęć może pomóc w formułowaniu tych antynomii, które są adekwatnymi obrazami realnych przeciwieństw. Rozwój teorii jest więc skutkiem rozwiązywania antynomii.

Batiszczew rozróżniał antynomie fałszywe i prawdziwe. „Fałszywe antynomie są jedynie problemami formułowanymi wciąż jeszcze fałszywie, wciąż jeszcze nie adekwatnie w stosunku do natury przedmiotu, a więc problemami jeszcze nie rozwiązywalnymi. I tylko antynomia prawdziwa daje w końcu obiektywną formę postawienia problemu - ujawnia problemowość w jej czystych przedmiotowych określeniach, bez tego, co pociąga za sobą »niedobra subiektywność«, co wnoszą czyjekolwiek przypadkowe psychologiczne indywidualne stany i postronne powiewy. Antynomia - to wyrażenie problemowości przedmiotu w języku samego przedmiotu" (Batiszczew, 1981, s. 265). Sprzeczności antynomii przezwycięża się tylko w ten sposób, że tworzy się teorie, które zgodnie z prawdą opisują i wyjaśniają zjawiska oraz przebieg procesów społecznych. Antynomia może być wyrazem słusznie postawionego problemu badawczego, ale nie jest równoznaczna z prawdziwością rezultatu jego rozwiązania. „Antynomia nie oddziela się od prawdy, jeśli jest to problem-antynomia znamionujący dalsze wznoszenie się od niepełnej, względnej wiedzy do wiedzy pełnej, prawdziwej. Jako taka antynomia nie odgrywa roli sprzeczności formalnologicznej i nie może stanowić argumentu na rzecz antagonistycznego przeciwstawienia logiki formalnej i dialektyki. Antynomia oddziela się od prawdy, jeśli sprzeczność tezy i antytezy występuje jako logiczna ślepa uliczka świadcząca o bezsilności, »nieprawdziwości«, sprzeczności teorii pretendującej do adekwatnego odzwierciedlenia obiektywnej rzeczywistości” (Porus, 1981, s. 313).

\section{Antynomie ontyczne}

W analizie demokracji chodzi o ukazanie sprzeczności, w tym obiektywnie istniejących antynomii o charakterze ontologicznym. Antynomią ontyczną jest taki stan rzeczy, gdy pewne atrybuty realnego zjawiska (już nie pojęcia) zaprze- 
czają innym. Zaprzeczają bezwarunkowo lub potencjalnie. Oto przykład: zasada proporcjonalności zastosowana w ordynacji wyborczej może w skutkach zaprzeczyć konstytucyjnej zasadzie równości (w wyborach „każdy głos znaczy tyle samo", ale w rezultacie wyborów w podejmowanych decyzjach już nie jest tak, że wola każdego obywatela liczy się tak samo, bo działa już zasada większości). Należy pamiętać o tym, że nie każda sprzeczność ontyczna jest antynomią, lecz tylko taka, która wiąże się z wewnętrznie sprzeczną naturą zjawiska, z pewnymi napięciami i dysharmonią w jego funkcjonowaniu. Antynomie funkcjonują np. wówczas, gdy forma zaprzecza treści; sposób działania zaprzecza celom tego działania; obiecana reprezentatywność zaprzecza interesom reprezentowanych i tożsamości z nimi; masy pracujące głosują na populistyczne ugrupowania prawicowe, które okazują się reprezentacjami oligarchii finansowej, a ugrupowania głoszące nacjonalizm okazują się finansowane przez kapitał międzynarodowy.

\section{Pojęcie sprzeczności dialektycznej}

Oprócz kategorii sprzeczności logicznej (istniejącej w logice formalnej) wyodrębniana jest sprzeczność dialektyczna (w logice dialektycznej). Jarosław Ładosz pisał, że „Sprzecznością dialektyczną danego zjawiska, rzeczy, procesu czy układu A nazywamy taki proces B, który jest koniecznym warunkiem istnienia, trwania i rozwoju A, a jednocześnie jego bieg stanowi przesłankę, możliwość unicestwienia A, doprowadza w określonych warunkach nieuchronnie do jakościowych przemian A. Nie wolno więc utożsamiać ze sobą sprzeczności logicznych i dialektycznych. [...] Częstym uproszczeniem jest również sprowadzanie przeciwieństw i sprzeczności dialektycznych do sił przeciwstawnych, napięć, czy tendencji działających z zewnątrz na określone zjawisko, przedmiot czy proces. Tymczasem, jeśli podejmować wyjaśnienie w tych terminach, przeciwieństwa i sprzeczności dialektyczne są raczej rozbieżnymi wewnętrznymi tendencjami zawartymi samej istocie rzeczy" (Ładosz, 1973, s. 107).

Z kolei Wiesław i Janusz Sztumscy stoją na stanowisku, że sprzeczność stanowi jedność dwóch przeciwieństw: „Przez przeciwieństwo dialektyczne rozumie się na ogół diametralnie różne ze względu na strukturę i funkcję istotne strony, tendencje jednego procesu czy zjawiska, które wzajemnie się zakładają, warunkują, dopełniają, przenikają i zarazem wzajemnie się negują, a których jedność i walka warunkuje zarówno istnienie zjawiska, jak i jego zmianę i rozwój” (Sztumski, Sztumski, 1977, s. 112). Dalej zaś dodają, że „każde z przeciwieństw jako element sprzeczności zawiera w sobie »swoje inne«, nie przestając być sobą; wzajemne »przenikanie« jest zarazem negacją, »wydobywaniem swojego innego«, czyli »samonegacją«. Sprzeczność dialektyczna jako »samonego- 
walność « nie jest już tylko czystą relacją, lecz staje się procesem samozmienności, samoruchu" (Sztumski, Sztumski, 1977, s. 113). Sprzecznością dialektyczną była dla nich istotna relacja przeciwstawnych momentów wewnętrznych układu czy zjawiska, która decyduje o tożsamości danego układu czy zjawiska i która czyni ten układ samoporuszającą się organiczną całością i negacją. Elementy sprzeczności wzajemnie się bowiem warunkują i negują. Wyjaśniali przy tym, że „,członów relacji »sprzeczność dialektyczna« nie mogą tworzyć pary dowolnych cech przedmiotów, lecz takie tylko cechy antynomiczne, które spełniając warunki współistnienia, warunkowania wzajemnego, oddziaływania lub negacji wzajemnej, wzajemnie się dopełniają, uzupełniają, czyli spełniają swego rodzaju »zasadę komplementarności«" (Sztumski, Sztumski, 1977, s. 119).

Nie jest właściwe ocenianie sprzeczności w kategoriach moralnego zła. Zdaniem Ładosza, ,jeśli zło, wada ma związek ze sprzecznością, to tylko taki, że nie sprzeczność sama, lecz jej zaostrzenie i niemożność rozwiązania jest hamulcem rozwoju i rodzi poczucie zła. Sprzeczność bowiem zawiera zawsze możliwość jej przezwyciężenia, a więc jest i rękojmią przezwyciężenia zła" (Ładosz, 1979, s. 24).

Zhak Aroĭo wskazywał, że do klasyfikacji sprzeczności dialektycznych wykorzystuje się różne kryteria: po pierwsze, klasyfikację opiera się na sferze, w której sprzeczności występują, po drugie, sprzeczności klasyfikuje się zależnie od wywołujących je przyczyn i źródeł, po trzecie, kryteria podziału są uzależnione od ostrości występowania przeciwieństw i sprzeczności między nimi, po czwarte, sprzeczności klasyfikuje się zależnie od ich charakteru. Można wskazać na następujące grupy sprzeczności: w zależności od celu, któremu klasyfikacja ma służyć - wewnętrzne i zewnętrzne; ze względu na pochodzenie - obiektywne i subiektywne, konieczne i przypadkowe; ze względu na istotę - antagonistyczne i nieantagonistyczne; ze względu na czasowy zasięg występowania - ogólne i specyficzne, permanentne i okresowe; ze względu na historyczny charakter więzi - istniejące w całej formacji lub tylko w jakiejś jej fazie; ze względu na terytorialny zasięg - narodowe i międzynarodowe (Aroĭo, 1984, s. 30, 32). Daniel Bell jako przykład sprzeczności ogólnej, która jednak szczególnie rozwinęła się w okresie kapitalizmu i jest treścią demokracji, podaje sprzeczność pomiędzy akumulacją i spożyciem, która ma dalsze rozwinięcie w sprzecznościach między ascetyzmem i zachłannością, cierpieniem i hedonizmem, między gospodarką i kulturą, między tym, co publiczne, i tym, co prywatne (Bell, 1984, s. 19).

Aroĭo wyróżniał trzy podstawowe grupy socjalnych sprzeczności w zależności od sfery ich występowania: sprzeczności socjologiczne, sprzeczności ekonomiczne i sprzeczności nadbudowy. Socjologiczne sprzeczności widział między elementami socjalnej struktury społeczeństwa, między głównymi sferami życia społecznego; sprzeczności między bytem społecznym i jego poznaniem; między produkcją materialną a innymi stronami życia społecznego, między bazą i nad- 
budową; między społeczeństwem i jednostką ludzką. Są to dla niego obiektywno-subiektywne sprzeczności, w których jedna strona jest obiektem (przyroda, siły wytwórcze, produkcja materialna), a druga - podmiotem socjalnym (człowiek, klasa, społeczeństwo). Sprzeczności ekonomiczne można jego zdaniem podzielić na dwie podstawowe grupy: pierwszą grupę stanowią sprzeczności, które odnoszą się do wszystkich społeczno-ekonomicznych formacji (np. między wartością użytkową i wartością); drugą grupę - sprzeczności specyficzne. Sprzeczności nadbudowy obejmują sprzeczności w dziedzinie polityki, prawa, estetyki, poglądów itd.

Aroǐo podkreślał, że zaproponowane klasyfikacje sprzeczności mają tylko metodologiczne znaczenie. Ze względu na swoją istotę określona sprzeczność może spełniać warunki i należeć do różnych grup, np. sprzeczność między towarem i pieniądzem jest jednocześnie fazowa, nieantagonistyczna, wewnętrzna, obiektywna, permanentna i konieczna, czyli spełnia wszystkie kryteria.

Sprzeczności ekonomiczne mają ogromny wpływ na sprzeczności polityczne (w tym sprzeczności systemu demokratycznego) i ideologiczne. „Podstawowa sprzeczność ekonomiczna najgłębiej wyjaśnia istotę ustroju społecznego, określa jego jakościowe osobliwości we wszystkich fazach i etapach rozwoju, wyjaśnia treść i kierunek rozwoju ustroju społecznego i ma decydujący wpływ na pozostałe sprzeczności. Główna ekonomiczna sprzeczność odnosi się do oddzielnych faz, często dłuższych lub krótszych etapów rozwoju społeczeństwa, w ramach których przybiera decydujące znaczenie jego dalszy rozwój. Każda pojedyncza sprzeczność może przerosnąć w główną w zależności od tych warunków, w których rozwija się społeczeństwo" (Aroĭo, 1984, s. 32-33). Każdy błąd podmiotu politycznego w kierowaniu ekonomiką, każda decyzja, która nie odpowiada obiektywnym potrzebom, rodzi nowe sprzeczności, które nie są konieczne, mają przypadkowy charakter, chociaż występują realnie.

Błędy są nieuchronne podczas wszelkiej działalności, co wynika z dialektyki podmiotu i przedmiotu. Odgrywają one rolę nie tylko negatywną, ale również pozytywną, pozwalają lepiej zrozumieć złożoną rzeczywistość, są źródłem doświadczeń i chronią przed popełnianiem większych błędów. Wszelki postęp i regres związane są z błędami. Chodzi nie o to, by nie popełniać błędów, ale by w nie nie brnąć i nie trwać w nich. Zdaniem Mirosława Karwata „Największym paradoksem błędów jest bowiem nie nieuchronność błędów i nie błędne koło błędów naprawy błędów ani też nie to, że okazują się zbawienne nawet dla sprawców, lecz to, że mogą być błędami obowiązkowymi i jedynie stusznymi" (Karwat, 2007a, s. 57).

Poszczególne sprzeczności nie są pojedynczym i odrębnym przykładem stosunków społecznych, lecz zjawiskiem mającym swoją szerokość i głębię. Igor Narski w związku z tym pisał, że „Każda sprzeczność jest struktura sprzeczno$s ́ c i$ skoordynowaną z innymi i podporządkowaną innym, wewnętrznie sprzecznym strukturom, które razem tworzą rozgałęzioną hierarchię. O ile sprzeczności 
formalnologiczne w ogólności redukują się do związków najprostszych, o tyle różnorodność struktur sprzeczności dialektycznych jest niewyczerpana. Każda struktura jest sprzeczna, a każda sprzeczność jest ustrukturowana" (Narski, 1981, s. 521). Jego zdaniem strukturalny charakter sprzeczności wyraża się m.in. w tym, że „sprzeczności, które osiągają stadium ostrego konfliktu, walki, nie występują w formie »czystej«, lecz z reguły są komponentami skomplikowanego układu wzajemnych zależności” (Narski, 1981, s. 523).

Podstawową sprzecznością kapitalizmu jest sprzeczność między społecznym charakterem produkcji i prywatno-kapitalistycznym sposobem zawłaszczania jej efektów, przejawiająca się jako sprzeczność między proletariatem a burżuazją. Sprzeczność ta nie ma wymowy pesymistycznej, lecz jest wyrazem optymizmu historyczno-dziejowego. „Siła napędowa społecznej anarchii produkcji coraz intensywniej zamienia znaczną większość ludzi w proletariuszy, a te masy proletariuszy z kolei położą w końcu kres anarchii produkcji” (Engels, 1972, s. 305).

Powszechnie znana jest wypowiedź Marksa z Przyczynku do krytyki ekonomii politycznej, którą można odnieść do sprzeczności międzyformacyjnych: „Na określonym szczeblu swego rozwoju materialne siły wytwórcze społeczeństwa popadają w sprzeczność z istniejącymi stosunkami produkcji lub - co jest tylko prawnym tego wyrazem - ze stosunkami własności, w obrębie których się dotąd rozwijały. Z form rozwoju sił wytwórczych stosunki te zamieniają się w ich kajdany. Wówczas następuje epoka rewolucji społecznej. Wraz ze zmianą podstawy ekonomicznej odbywa się szybciej lub wolniej przewrót w całej olbrzymiej nadbudowie. [...] Żadna formacja społeczna nie ginie, zanim się nie rozwiną wszystkie siły wytwórcze, którym daje ona dostateczne pole rozwoju, a nowe, wyższe stosunki produkcji nie zjawią się nigdy na jej miejsce, zanim w łonie starego społeczeństwa nie dojrzeją materialne warunki ich istnienia" (Marks, 1966, s. 9).

\section{Sprzeczności antagonistyczne i nieantagonistyczne}

Największy wpływ na warunki funkcjonowania i sprzeczności samej liberalnej demokracji mają antagonistyczne sprzeczności społeczne. Ładosz wskazywał na cztery podstawowe sposoby rozumienia sprzeczności antagonistycznych i nieantagonistycznych. W pierwszym rozumieniu sprzeczności antagonistyczne cechuje gwałtowny przebieg i rozwiązywanie ich poprzez nagłe wybuchy, raptowność. W drugim rozumieniu doraźne rozbieżności interesów przeważają nad długofalowymi i wspólnymi. W trzecim rozumieniu sprzeczności antagonistyczne to takie, które rozwiązywane są z użyciem przemocy, w szczególności siły zbrojnej, są stale tą przemocą zagrożone. W czwartym ro- 
zumieniu sprzeczności antagonistyczne to takie, których podstawą jest stosunek wyzysku człowieka przez człowieka. Ładosz zauważa przy tym, że ogólnie znaną prawdą jest również stwierdzenie, że w określonych warunkach sprzeczności nieantagonistyczne mogą przerastać w sprzeczności antagonistyczne. Zakresy tych sprzeczności mogą krzyżować się parami. „Sprzeczności antagonistyczne w rozumieniu czwartym mogą być rozwiązywane w sposób nieantagonistyczny w rozumieniu pierwszym $\mathrm{i}$ trzecim, $\mathrm{tj}$. niegwałtownie $\mathrm{i}$ bez bezpośredniego zastosowania zbrojnej przemocy w skali masowej. [...] Natomiast antagonizm w rozumieniu czwartym zawsze jest złączony w sposób konieczny z antagonizmem w rozumieniu trzecim, gdy nadać mu pewien określony sens". Zastrzegał przy tym, że „Nie wszelka jednak przemoc jest związana z wyzyskiem. Przemoc zbrojna $\mathrm{w}$ życiu społecznym i rozwiązywanie sprzeczności z jej pomocą stosowane było i w bezklasowym społeczeństwie pierwotnym" (Ładosz, 1979, s. 29). Nie każda sprzeczność antagonistyczna musi prowadzić do konfliktu politycznego czy zbrojnego. Do konfliktu mogą doprowadzić także sprzeczności nieantagonistyczne, które ulegną zaostrzeniu lub przerosną w antagonistyczne.

Z kolei zdaniem Stanisława Kozyra-Kowalskiego sprzeczności antagonistyczne to takie, które nie mogą być rozwiązane bez wyeliminowania przynajmniej jednej strony występującej w sprzeczności. Przykładami takich sprzeczności były, jego zdaniem, sprzeczności między wyzyskiwaczami a wyzyskiwanymi: właścicielami niewolników a niewolnikami, panami feudalnymi i chłopami, burżuazją i proletariatem. Rozwiązanie sprzeczności antagonistycznej możliwe jest na drodze rewolucyjnej zmiany ustroju (Kozyr-Kowalski, 1982, s. 339).

Daniel Bell, który odrzucał marksistowską ideę o „klasie panującej”, uważał, że antagonistyczne sprzeczności kapitalizmu wynikają z dokonującego się społecznego podziału pracy, z ,antagonistycznych zasad wyznaczających struktury techniczno-ekonomiczne, polityczne i kulturowe społeczeństwa” (Bell, 1994, s. 15). Antagonizm w dziedzinie techniczno-ekonomicznej „opiera się [...] na osiowej zasadzie oszczędności: dążenie do wydajności poprzez rozbicie wszelkich czynności na najdrobniejsze składniki kosztów jednostkowych, zdefiniowanych przez system sprawozdawczości finansowej. Osiowa struktura oparta na specjalizacji i hierarchii polega na biurokratycznej koordynacji. Jednostki z konieczności traktuje się zatem nie jako osoby, lecz jako rzeczy, jako narzędzia maksymalizacji zysku" (Bell, 1994, s. 16). Przy czym, w przeciwieństwie do Marksa, Bell zysku nie traktował jako wyrazu specyficznego stosunku produkcji pomiędzy prywatnym właścicielem środków produkcji a najemną siłą roboczą, lecz jako wynik ,wydajnego wykorzystania zasobów”. W przeciwieństwie do Marksa, który zysk łączył z kapitalizmem, Bell uważał, że zysk jest pożądanym celem każdego systemu ekonomicznego.

Zdaniem Bella w dziedzinie polityki antagonizm powodowany jest ,,przez napięcia między wymogami biurokracji i równości”, gdyż ,porządek polityczny - aby wyrównać stanowiska i nagrody wytwarzane przez system ekonomiczny - 
coraz bardziej interweniuje w życie gospodarcze i społeczne" (Bell, 1994, s. 16). Z kolei sprzeczności antagonistyczne w dziedzinie kultury wynikają stąd, że istnieje sprzeczność pomiędzy jednostką dążącą do własnej satysfakcji a „wymogami roli, jaką dana jednostka pełni w porządku techniczno-ekonomicznym” (Bell, 1994, s. 16).

Zdaniem autora Kulturowych sprzeczności kapitalizmu, antagonizm uległ zaostrzeniu $\mathrm{w}$ procesie rozwoju kapitalizmu, ale nie wiązał się z nasileniem walk klasowych. „Antagonizm pogłębiał się w miarę jak organizacja pracy i produkcji ulegała biurokratyzacji, a jednostki sprowadzane były do odgrywania ról; w rezultacie normy obowiązujące $\mathrm{w}$ miejscu pracy stawały się coraz bardziej niezgodne z usilnym dążeniem do samoeksploracji i samogratyfikacji” (Bell, 1994, s. 24). Sprzeczności stwierdzane przez Bella odnoszą się często do niezwiązanych z sobą zjawisk lub jedynie sprzeczności logicznych. W wydaniu Bella jest to więc quasi-dialektyka rzeczywistych sprzeczności i antynomii.

Niezależnie od tego, jak zdefiniujemy antagonizm, jego eliminacja nie jest niestety tak prosta i łatwa, jak się na pierwszy rzut oka wydaje. Najłatwiejsze jest być może wyeliminowanie przemocy politycznej, ale przemoc i przymus, wbrew deklaracjom wielu polityków, pozostają trwałym elementem stosunków politycznych. Jerzy Kochan przestrzega przed uproszczeniami w sprawie rozumienia i eliminacji inaczej rozumianego antagonizmu. Likwidacja niewolnictwa oznaczała rzeczywiście likwidację właścicieli niewolników, ale i niewolników. „Przykład ten jest o tyle dobry, że ujawnia możliwość likwidacji niewolnictwa nie w wyniku likwidacji klasy antagonistycznej przez niewolników, jakiejś wersji powstania Spartakusa, lecz w rezultacie bardziej złożonego splotu historycznych okoliczności, wskazuje również na ciekawy przykład historyczny, w którym antagonistyczny układ klasowy nie jest podstawowy, określający dla danej epoki czy danego społeczeństwa, lecz ma w swej istocie charakter peryferyjny, regionalny" (Kochan, 2007, s. 56). Tę uwagę Kochana można również próbować odnieść do likwidacji wskazywanego przez marksistów antagonizmu proletariatu i burżuazji czy też do „demokracji proletariackiej” i „demokracji burżuazyjnej".

\section{Sprzeczności powstałe z oddziaływań zewnętrznych}

Sprzeczności liberalnej demokracji z pewnością były łagodzone w wyniku podstawowej sprzeczności antagonistycznej w XX wieku pomiędzy socjalizmem i kapitalizmem w skali międzynarodowej. Upadek „realnego socjalizmu” i rozbicie rewolucyjnego ruchu robotniczego spowodowały ponowne zaostrzenie sprzeczności własnych gospodarki rynkowej i liberalnej demokracji. 
Stoję na gruncie dialektycznego związku sprzeczności logicznej i dialektycznej, nie zajmuję się wyszukiwaniem sprzeczności formalnych, chociaż jest ich ogrom $\mathrm{w}$ przepisach poszczególnych gałęzi czy dziedzin prawa, prawach i obowiązkach obywatelskich, zasadach prawa wyborczego. Dla niektórych osób sprzeczności i niekonsekwencje stanowią wynik niedbalstwa i pośpiechu prawników i ustawodawców. Osoby te nie przyjmują do wiadomości, że są one odbiciem istniejących sprzeczności społecznych i że związane są z samą istotą neoliberalnej demokracji. Domagają się zatrudnienia lepszych prawników i ekspertów z ,zewnątrz”, bezstronności sądów, zapominając, że prawo jest stronnicze dlatego, że stronniczy są stanowiący je posłowie, którzy próbują pogodzić sprzeczności społeczne. Jeśli negują lub nie potrafią właściwie odczytać istniejących sprzeczności społecznych, ci poszukują ich zewnętrznych przyczyn, obiecują ,idealne” rozwiązania prawne, sporom o poszczególne słowa są w stanie przypisać rewolucyjne znaczenie.

Sprzeczności współczesnej neoliberalnej demokracji nie można ograniczać do sprzeczności zewnętrznych - między państwami demokratycznymi a państwami „muzułmańskimi”, „totalitarnymi”, „zbójeckimi”. Te sprzeczności zewnętrzne często wykorzystywane są w celach tożsamościowych, jednoczenia własnych społeczeństw rozdzieranych przez konflikty i sprzeczności wewnętrzne.

W pojęciu demokracji nawet wewnątrz Unii Europejskiej istnieje pewien dysonans i dysharmonia między tradycjami zaawansowanych demokracji zachodnich i standardami Unii Europejskiej a kolorytem tradycji ustrojowych i mentalnością krajów Europy Środkowej, w tym Polski i Węgier, co nieuchronnie prowadzi do konfliktów pomiędzy rządem Zjednoczonej Prawicy i partią Fidesz Viktora Mihálya Orbána a Unią Europejską.

\section{Typowe antynomie demokracji}

Demokracja zawiera liczne antynomie. „Władza ludu” we wszelkiej postaci nieuchronnie okazuje się antynomią, stąd też władza ludu - urzeczywistniana poprzez mechanizm wyborów i nacisku opinii publicznej - wyłania władzę nad ludem, która w okresie pomiędzy wyborami wymyka się spod kontroli, a wykorzystuje swoje prerogatywy tak, aby zapewnić sobie wygodny dla siebie wynik wyborów i pogłębić „władzę nad ludem”. W rezultacie „władza nad ludem” pojawia się znacznie częściej i trwa dłużej niż „władza ludu nad władzą”. Być może związane jest to z samą genezą demokracji ateńskiej, która była wynikiem starcia dwóch grup oligarchii pragnących wykorzystać „lud” w swoich interesach. Lud mógł decydować, a oligarchia mogła zachować system niewolnictwa, bogactwo i swoje przywileje. 
Istnieje sprzeczność pomiędzy formalną równością prawną obywateli, m.in. w roli wyborców, a faktycznym uzależnieniem ich wpływu (np. możliwości kariery politycznej) od ich statusu materialno-finansowego lub posiadania sponsorów (co czyni kandydatów do roli politycznej zakładnikami tych sponsorów). Jest w tym niezgodność między formalną równością obywateli wobec prawa a uzależnieniem ich wpływu od ich statusu materialnego.

Konsekwencją tego jest nierówna faktycznie, choć równa formalnie wolność. Wolność (szczególnie: wolność słowa, zrzeszania się) nie obejmuje m.in. wolności głoszenia poglądów antydemokratycznych i zrzeszania się w celu dyskryminacji, propagowania rządów autorytarnych. Jednak dochodzą one do głosu właśnie z powołaniem się na wolność słowa i swobodę zrzeszania się, a próby ograniczania lub eliminowania (np. delegalizacji) idei i ugrupowań antydemokratycznych obwiniane są o zamach na te wolności. W rezultacie nikt sobie z tą antynomią nie radzi, gdy rozkwitają ruchy rasistowskie, ksenofobiczne, nawet faszyzujące, gdyż często istnieje płynna granica między poglądami i ruchami „demokratycznymi” a „niedemokratycznymi” i poszczególne siły polityczne nie chcą ujawnić swych interesów ekonomicznych i doprowadzić do ich konfrontacji. Dlatego wyborcza droga wyłaniania władz i legitymacji wyborczej sama w sobie zawiera pewną pułapkę, czego przykładem było uzyskanie w przeszłości „mandatu demokratycznego” przez NSDAP.

Pewnym paradoksem jest to, że mniejszość społeczno-polityczna może stać się większością (w sensie formalnym, jako parlamentarno-rządowa), która ignoruje, a nawet uciska jakąś rzeczywistą większość. „Legitymację większości” (w parlamencie) może uzyskać mniejszość obywateli (na przykład PiS-owska większość parlamentarna była ukształtowana w 2015 r. w imieniu mniejszości społeczeństwa, gdy głosowało na nią tylko 19\% uprawnionych do głosowania). Typową antynomią dla demokracji jest sprzeczność między „legitymacją większości" a faktem, że większość (parlamentarna, rządowa, a nawet ta sondażowa) jest efektem posłuchu czysto statystycznej i niejednorodnej w interesach i poglądach większości wobec zorganizowanej, jednolitej w dążeniach mniejszości, jaką jest ruch czy partia. Zorganizowana i zdeterminowana mniejszość może narzucać wolę amorficznej lub skonfliktowanej wewnętrznie większości społeczeństwa i władzy. Ruch ORDO IURIS, dążący do obrony życia poczętego w różnych wcieleniach, małżeństwa jako związku kobiety i mężczyzny oraz rodziny, jest w stanie wywierać wpływ na władzę ustawodawczą i wykonawczą.

Istnieje też sprzeczność między formalnie demokratycznym wzorcem ustrojowym i normami konstytucyjnymi demokracji liberalnej a autorytarnym lub anarchicznym typem mentalności wielu grup społecznych i reprezentujących je polityków.

Czy antynomie demokracji liberalnej mogą być przezwyciężone w ramach jej funkcjonowania, „doskonalenia”, reformowania, czy też są swego rodzaju pułapką? Ta kwestia zasługuje na osobne przemyślenie. 


\section{Bibliografia}

[Arol̆o, Zh.Zh.] Аройо, Ж. (1984). Экономические противоречия при сочиализме. Сущность, проявления, разрешение. Москва: Политиздат.

Batiszczew, G. (1981). Dlaczego antynomia oddziela się od prawdy? W: H. Widłaszewski (red.), Sprzeczność dialektyczna. Praca zbiorowa. Warszawa: Książka i Wiedza.

Bell, D. (1994). Kulturowe sprzeczności kapitalizmu. Przeł. S. Amsterdamski. Warszawa: Wydawnictwo Naukowe PWN.

Bensaïd, D. (2012). Permanentny skandal. W: G. Agamben i in., Co dalej z demokracja? Warszawa: Książka i Prasa.

Engels, F. (1972). Anty-Dühring. Przewrót w nauce dokonany przez pana Dühringa. W: K. Marks, F. Engels, Dzieła, T. 20. Warszawa: Książka i Wiedza.

Głagolewa, E. (1981). Czy prawdziwe są przeciwstawne określenia wchodzące w skład pojęcia teoretycznego? W: H. Widłaszewski (red.), Sprzeczność dialektyczna. Praca zbiorowa. Warszawa: Książka i Wiedza.

Rozental, M. i in. (1977). Historia dialektyki marksistowskiej. Od powstania marksizmu do etapu leninowskiego. Warszawa: Książka i Wiedza.

Karwat, M. (2007a). Pesymistyczna teoria błędów. W: M. Karwat (red.), Paradoksy polityki. Warszawa: Dom Wydawniczy Elipsa.

Karwat, M. (2007b). Wprowadzenie. Pochwała paradoksu. W: M. Karwat (red.), Paradoksy polityki. Warszawa: Dom Wydawniczy Elipsa.

Kochan, J. (2007). Życie codzienne $w$ matriksie. Filozofia spoleczna w ponowoczesności. Warszawa: Wydawnictwo Naukowe Scholar.

Kostecki, W. (2007). Wielostopniowa paradoksalność polityki w ujęciu Ricoeura. W: M. Karwat (red.), Paradoksy polityki. Warszawa: Dom Wydawniczy Elipsa.

Kościuszko, K. (2015). Popper - dogmatyzm - dialektyka. Humanistyka i Przyrodoznawstwo, 21, 9-24.

Kozyr-Kowalski, S. (1982). Sprzeczność antagonistyczna. W: T.M. Jaroszewski i in. (red.), Słownik filozofii marksistowskiej. Warszawa: Wiedza Powszechna.

Ładosz, J. (1973). Materializm dialektyczny. Warszawa: Państwowe Zakłady Wydawnictw Szkolnych.

Ładosz, J. (1979). Sprzeczności w rozwoju społeczeństwa socjalistycznego. W: J. Ładosz (red.), Materializm historyczny. Materiaty Ogólnopolskiego Zjazdu Filozoficznego. Wrocław, Warszawa, Kraków, Gdańsk: Ossolineum.

Marks, K. (1966). Przyczynek do krytyki ekonomii politycznej. W: K. Marks, F. Engels: Dzieła. T. 13. Warszawa: Książka i Wiedza.

Narski, I. (1981). Dialektyczna sprzeczność i logika poznania. Warszawa: Państwowe Wydawnictwo Naukowe.

Popper, Karl R. (1999). Czym jest dialektyka? W: K. R. Popper, Droga do wiedzy. Domysty i refutacje. Warszawa: Wydawnictwo Naukowe PWN.

Porus, W. (1981). Nie „rozdzielać”, lecz rozróżniać. W: H. Widłaszewski (red.), Sprzeczność dialektyczna. Praca zbiorowa. Warszawa: Książka i Wiedza. 
Raj, M.C. (2012). Dialectic Democracy. https://mcrajauthordotcom.wordpress. com/2012/09/01/dialectic-democracy (data dostępu: 9.09.2021).

Sztumski, W., Sztumski, J. (1977). Materializm dialektyczny a współczesne nauki szczegółowe. Warszawa: Książka i Wiedza. 